\title{
Evidence of cat (Felis catus) fur exploitation in medieval Iberia
}

Lluís Lloveras (1), Richard Thomas (2), Albert Garcia (1), Francesc Florensa (3), Sergi Segura (3), Esther Medina (3), Eva Orri (4), Jordi Nadal (1).

(1): SERP. Secció de Prehistòria i Arqueologia. Universitat de Barcelona. C/Montalegre 6-8. 08001. Barcelona. Spain.

(2): School of Archaeology and Ancient History, University of Leicester, University Road, Leicester, LE1 7RH, UK.

(3): ATICS S.L.C/Torrent de les Piques, 36 baixos. 08304. Mataró. Spain. atics@atics.org

(4): GEPEG. Secció de Prehistòria i Arqueologia. Universitat de Barcelona. C/Montalegre 6-8. 08001. Barcelona. Spain.

Corresponding author: Lluís Lloveras (1luislloveras@ub.edu)

\begin{abstract}
While the bones of domestic cats (Felis catus) are recovered from archaeological sites in Iberia routinely, they are rarely subjected to detailed analysis. Consequently, there is limited understanding of the nature of cat-human relations, especially in contrast to northern European regions. In this paper we present a unique assemblage of 899 cat bones recovered from the medieval site of El Bordellet (Vilafranca del Penedès, Spain) and dated between the end of the $10^{\text {th }}$ century $\mathrm{AD}$ and the beginning of the 11 th century $\mathrm{AD}$. Zooarchaeological and taphonomic analysis provides the first clear evidence of skinning related to cat fur exploitation in Christian medieval Iberia.
\end{abstract}

Keywords: Felis catus, Skinning, Fur exploitation, Middle Ages, Iberian Peninsula, Taphonomy.

Running head: Cat fur exploitation in medieval Iberia 


\section{Introduction}

Following their domestication, probably in the Middle East during the Neolithic (Davis, 1987; Driscoll et al., 2007; Vigne and Guilaine, 2004; Vigne et al., 2004), domesticated cats (Felis catus) spread across Europe, arriving in northernmost regions as trade networks became established during the Roman occupation (Bökönyi, 1974; Bobis 2000; De Grossi, 1997; Gautier, 1990). While the bones of domestic cats are recovered regularly from Roman sites in the Iberian Peninsula, they may have been first introduced into the region by Phoenician traders (Driesch, 1973; Lignereux et al., 2000). The infrequency of cat bones relative to other mammals, however, has meant that they have not been subjected to detailed analysis.

Yet, cats provide a valuable lens through which human attitudes towards non-human beings can be explored. The behaviour of cats is unique amongst domesticated animals, varying markedly according to the degree of socialisation they experience as kittens, evoking complex and often contradictory human responses and projections. Cats have been exploited for their capacity to catch rodents, 'farmed' for fur, used in medicine, persecuted as pests and familiars, kept as companion animals and revered as deities Depending on their colour (and where in the world they are encountered), they can be bringers of either good or bad luck (Bobis, 2000; Metzler, 2009).

In this paper, we present a unique assemblage of 899 cat bones recovered from the medieval site of El Bordellet (Vilafranca del Penedès, Spain) and dated between the end of the $10^{\text {th }}$ century $\mathrm{AD}$ and the beginning of the 11th century $\mathrm{AD}$. In medieval Iberia, cat remains have been recorded from several archaeological sites (Table S1). However, in most cases zooarchaeological data are rarely published in detail and there are no in-depth taphonomic studies. Consequently, there is little understanding of the complexity of human-cat relations and how this changed through time in the region. In this study, a zooarchaeological and taphonomic analysis is conducted to understand the origin of the cats at El Bordallet and to deepen understanding of human-cat relations in medieval Iberia.

\section{Materials}

The site of El Bordellet is located at Vilafranca del Penedès (Barcelona, Spain) (Fig. 1). It is an open-air site that was excavated in 2010 in advance of highway construction. A total of 59 (mostly storage) pits were excavated dating from the Neolithic to the Modern period.

Based on artefactual evidence, nine pits were dated to the medieval period. These structures seem to have been crop storage pits that were backfilled with rubbish once they had gone out of 
use, as evidenced by broken pottery, charcoal, ash and animal bones. The temporal and contextual relationship between the different pits is difficult to establish; however, they probably relate to a rural settlement that has yet to be excavated (Segura and Medina, 2010). Faunal remains from these pits were dominated by sheep (Ovis aries), followed by goats (Capra hircus), cattle (Bos taurus) and domestic pigs (Sus domesticus). Dogs (Canis familiaris) and equines (Equus sp.) were also present albeit less frequently. One of the pits (E-21) was notable because it contained an unusual concentration of cat remains. The structure was a storage pit ( $75 \mathrm{~cm}$ deep and $120 \mathrm{~cm}$ in diameter) with a circular floor plan, cylindrical section and a flat base (Fig. S1). The homogeneity of the sediments indicates that the pit was filled in a single episode. Other animal remains recovered alongside the cat bones included: a whole horse skull (Equus caballus); a goat horn fragment; and a chicken (Gallus domesticus) eggshell that was probably deposited complete as evidenced by the position of the fragments. The cat assemblage was isolated from other animal remains; the cats appear to have been articulated and, with the exception of one individual, deposited on top of each other (Fig. 2). One of the cat bones was radiocarbon dated to $1,040 \pm 30 \mathrm{BP}$ (cal AD 970-1025) (beta-406999).

The bones from E-21 were collected by hand and separated as individuals by the excavators. However, because the remains were stacked, some bones were not correctly attributed. Moreover, skulls and mandibles were not kept together with their corresponding postcranial remains.

\section{Methods}

Skeletal element abundance was evaluated using the Number of Identified Specimens Present (NISP), Minimum Number of Elements (MNE) and Minimum Number of Individuals (MNI) as well as their relative frequencies (Grayson, 1984). The relative abundance (\%RA) for each skeletal element was calculated after Dodson and Wexlar (1979) to assess the ratio of observed to expected elements. Specimens were recorded as either complete or fragmented, and the number and percentage of complete elements were calculated. Breakage was classified to distinguish fresh (green) from dry fractures (Johnson, 1985; Villa and Mahieu, 1991).

Age at death was estimated using the epiphyseal fusion state of long bones (Smith, 1969) as well as tooth eruption and wear (Berman, 1976). Measurements were taken on mandibles and crania following von den Driesch (1976) to distinguish wild and domestic forms and assess their size in relation to other medieval samples from across Europe. 
The taphonomic analysis included the observation of bone surface alterations generated by different processes. Damage to the bone surface was examined macro- and microscopically. Each specimen was observed under a light microscope (x10 to x40 magnification).

Burning was recorded in terms of presence/absence and based on colour changes that occurred during exposure to heat (Shipman et al., 1984; Stiner et al., 1995).

Cut marks were classified following the criteria used in Greenfield (1999) and Lewis (2008). They were tallied by element type and anatomical zone, and classified as longitudinal, transverse or oblique, depending on their orientation relative to the primary axis of the skeletal element.

Gnawing damage and the presence of tooth marks caused by predators were recorded. Tooth marks were classified as: tooth punctures (TPU), tooth pits (TPI), notches (NO), scoring (SCO), and crenulated / fractured edges (CRE) (Haynes, 1980; Binford, 1981).

Other post-depositional changes, such as manganese oxide precipitation, calcite coating and root etching (e.g., Lyman, 1994), were also noted. Each of these alterations was classified as present/absent to determine the influence of diagenetic processes upon the assemblage.

All bones and teeth were subjected to macroscopic examination for evidence of pathology.

\section{Results}

A total of 899 bone and tooth fragments were identified to skeletal element and attributed to domestic cat. Based on cranial elements and lumbar vertebrae counts, the MNI in the assemblage is nine: there was an MNE of 736 (Table 1). Due to the co-mingling of some individuals during excavation, not all skeletal elements could be associated with an individual.

\subsection{Anatomical representation}

Table 1 presents the anatomical composition of the identified remains. The entire skeleton is represented but in different proportions. The relative abundance of skeletal elements (RA\%) is also shown in Table 1 and Fig. S2. The mean value (56.2\%) is low, indicating a moderate loss of bones in the assemblage. The skeletal profile shows a strong bias against the smallest elements: patellae (11.1\%); 1st/2nd and 3rd phalanges (6.53\% and $0.61 \%$ respectively); and tarsal $(8.88 \%)$ and carpal bones $(0.79 \%)$. By contrast, the best-represented elements were: crania (100\%); vertebrae (particularly lumbar vertebrae, 95.2\%); mandibles (77.7\%); and long bones $(72.7 \%-77.7 \%)$. 


\subsection{Age and size estimation}

The presence of permanent dentition in all individuals indicates that they were aged above six months at the time of death. Analysis of epiphyseal fusion generates an age range of 9 to 25 months for most specimens (Table 2). Only one individual (number 9 in Table 2) exceeded 25 month of age; however, tooth wear suggests that it was not much older. Whilst the determination of absolute age should always be undertaken cautiously, because skeletal and dental ontogeny can be affected by diet and other factors, it is clear that the sample consisted of a group of young animals that probably died between one and two years of age.

The metrical data are presented in Table 3. Analysis of all mandible measurements revealed three discrete clusters (Fig. S2; Fig. 3). By way of example, a scatterplot of the vertical ramus height against the total mandible length (Fig. 3), revealed a group of three individuals at the bottom left, a larger and more discrete group (four individuals) in the upper central area and one individual plotted to the upper right. To assess whether this distribution reflects the small size of the sample or a biological phenomenon, the mandible measurements from El Bordellet were compared with samples from contemporary sites (Fig. S3). This analyses reveals that the distribution from El Bordellet is consistent with the pattern observed at other sites.

This classification seems to reflect the age distribution of the cats. Based on epiphyseal fusion data (Table 2), three age groups were observed: three individuals were younger than 13 months; five were aged between 15 and 25 months; and one individual was older than 25 months. The relationship between size and age distribution in the sample is supported by the concordance between the individuals in the three age and size groups. The influence of sex in the size variation is impossible to assess due to the exclusive presence of sub-adults.

Measurements of the total length of the mandibles from El Bordellet were compared with other medieval cat samples with available data (after Luff \& Moreno-García 1995 and De Venuto 2006): Lion Walk in Colchester, Castle Mall in Norwich and Benet's Court in Cambridge, UK; Haithabu in Schleswig-Holstein and Höxter in Nordrhein-Westfalen, Germany; and Canne della Battaglia in Barletta, Italy. The results show (Table 4) that the cat mandibles from El Bordellet were statistically indistinguishable in length from all sites except Benet's Court, which were significantly smaller (Table 4). The small size of the Benet's Court cats was discussed by Luff \& Moreno-García (1995) who suggested that it could reflect the presence of a smaller morphotype. However, the age at death of the cats may also play a role in this issue as $59 \%$ of cats in the assemblage were aged under seven months: at El Bordellet site, only $33 \%$ of individuals fell into this age category. 


\subsection{Breakage}

The percentage of complete elements was high $(\mathrm{N}=608,82.60 \%)$. Values vary by bone type, with the lowest percentages obtained for the more fragile bones: cranium (33.3\%); scapula (53.8\%); ribs (31.5\%); and fibula (37.5\%). The percentage of fragmented metatarsals $(53.2 \%)$ was also low compared to other skeletal elements (Table 1).

Most bone fractures $(270,92.8 \%$ of fractures) were attributed to dry breakage, presenting straight, rough edges, indicating that they were caused by diagenetic processes during or after excavation. Green fractures were only observed on 24 elements ( $2.7 \%$ of NISP): one ulna, three metacarpals and 18 metatarsals. Green fractures on bones were associated with cuts and chops made to remove part of the autopodia in some individuals (Table 2). Two further cases of fresh fractures affected individuals one and five. In both cases, one of the upper canines was cut (one in each individual, Fig. 4). These fractures are clearly anthropogenic but their cause is unknown.

\subsection{Bone surface modifications and pathologies}

No burning or heat-altered damage was observed in the assemblage.

Cut marks were identified in all nine individuals (Table 2) with a relatively high frequency (5.3\% of NISP) compared with the results obtained in experimental skinning studies involving similar sized animal carcasses (Lloveras et al., 2009). In all cases, the cut marks were generated by a metal blade (Greenfield, 1999; Lewis, 2008). Two types of marks were detected:

1) Marks of moderate and strong depth, where the blade of the tool has penetrated deep into the cortical bone creating a macroscopically-visible mark, sometimes producing a clear fracture through the cancellous bone. These marks were recorded on six individuals. They were observed on metatarsals $(\mathrm{N}=25,49 \%$ of recovered metatarsals) and metacarpals $(\mathrm{N}=2,9.1 \%$ of recovered metacarpals) and one distal ulna (Table 2). Marks were situated on both dorsal and plantar sides of the shaft, transverse to the principal axis of the bone. These marks are conventionally interpreted as evidence of skinning (Fig. 5).

2) Marks of superficial depth that produce light damage and were hard to see without the aid of a light microscope. These marks were recorded on all individuals. They were commonly observed on different areas of the skull (8/9 individuals) and mandibles (6/9 individuals). On mandibles, most cut marks were transverse to the principal axis of the bone, located beneath the diastema or below the canine or the first premolar alveolus and always on the buccal side. On the skull, transverse, longitudinal and oblique cut marks were observed, most of which were situated on the maxilla, parietal, frontal and, in a few cases, temporal bones (Table 2). These 
marks are associated with skinning, during the separation of the skin from muscles and bone in the eyes, cheek and snout areas (Fig. 6).

There is no evidence of carnivore or raptor activity in the form of gnawing or tooth/beak marks. Post-depositional alterations such as manganese oxide precipitation or calcite coating were not observed. Root etching damage was identified on 410 specimens (45.6\%).

No pathology was observed.

\section{Discussion}

The domestic cat remains identified at medieval El Bordellet were intentionally deposited as complete (or almost complete) individuals, as evidenced by the fact that the bones were preserved in their original anatomical position. Despite the scarcity of very small elements (phalanges, patellae, carpal/tarsal bones), the anatomical representation profile indicates that whole skeletons were present. The rarity of those elements may reflect the action of two taphonomic processes: differential recovery during excavation, resulting in the loss of very small remains such as patellae; and butchery practice.

Butchery marks comprised localized fractures and cut marks which are likely the result of skinning: the frequency, location, orientation and intensity of cut marks and fractures are consistent with modifications arising from experimental skinning of different small/mediumsized animals (Crezzini et al., 2014; Lloveras et al., 2009; Mallye, 2011). The marks recorded in the archaeological sample on the crania and mandibles have been replicated experimentally during the removal of the skin from around the eyes and the snout. Cut and chop marks observed on metatarsals are coincident with those left by the blade when the skin is removed by cutting above the tarsals. It appears that the metatarsals from El Bordellet were cut during the removal of the skin from the feet of the hind limbs. This did not occur in the forelimb feet, where the lack of cut marks and the almost absence of metacarpals seem to indicate that the autopodia of the forelimb were dislocated manually by pulling up to the carpal bones. TThis skinning procedure may have resulted in the loss of some small elements such as carpal/tarsal bones or phalanges that remained attached to the skin of the animals. This could also explain the scarcity of some larger bones in the sample such as metacarpals and the distal parts of the fragmented metatarsals. Similar taphonomic patterns are described in other medieval cat assemblages where fur exploitation has been suggested (Albarella \& Davis, 1994; Albarella et al., 1997; Fairnell, 2003; Hatting, 1990; Luff \& Moreno-García, 1995). 
The young age at death of the cats supports the interpretation of the deposit from El Bordellet as the waste from cat fur exploitation and has parallels in other samples (Luff \& Moreno Garcia 1995; Maltby, 1979; Noodle, 1977; Serjeantson, 1989). This phenomenon probably reflects the fact that there is an optimal age for cat fur exploitation, when animals are sufficiently large but their fur is still free of damage, parasites or disease.

In summary, the type of deposit, the age of the cats analysed, the breakage pattern and the presence and location of cut marks indicate the systematic procurement of cat fur at El Bordellet. The anatomical representation, the scarcity of fresh fractures, the lack of cut marks related to other types of butchery practice (disarticulation, defleshing) and the absence of burning, all indicate that these cats were not eaten.

Written sources demonstrate the importance of the cat fur trade during the Middle Ages, particularly in Anglo-Saxon regions, despite its fluctuating value (Bobis, 2000; Bonde, 2001; McCormick, 1988; Moloney \& Coleman, 1997). The geographical focus of this evidence in NW Europe and particularly Britain, could be explained by a cultural tradition in the use and distribution of cat fur in this period, which perhaps originated in the area of Norman influence (Morales, 1991). However, a more plausible explanation, backed up by this study, is the scarcity of zooarchaeological studies of medieval assemblages in Mediterranean countries, especially where a thorough taphonomic analysis has been conducted. In these regions, only two cases from Italy, Masseria quattro Macine and Canne della Bataglia (Arthut et al., 1996; De Venuto 2006), have been published. In Christian medieval Iberia a probable case of cat skinning was recorded at Zornoztegui II site (Grau, 2014). Nevertheless, only one cut mark on the femur was registered in this case, which is perhaps more likely evidence of meat consumption than fur exploitation. Cat remains from other sites in the same region as El Bordellet are interpreted as evidence for commensal or pet animals (see Table S1). The remains of two skinned cats were recovered from the medieval site of C/Lozano Sidro 16 in Priego de Córdoba (Martínez and Carmona, 2013), albeit from a different (Muslim) cultural context.

The absence of cat meat consumption at El Bordellet is notable, since it is associated with the exploitation of fur at a number of medieval sites across Europe (De Grossi and De Venuto, 2006; Grau 2014; Luff and Moreno-García, 1995). Yvinec (1993) has argued that domestic and wild carnivores contributed $10 \%$ of the meat consumed during this period in France. Furthermore, the use of cats as food is also documented in recipe books published in the same region as the site of El Bordellet, such as Mestre Robert's Llibre del Coch: the first printed cookbook in Catalan written in the second half of the XV century and printed in 1520 (Mestre Robert, 1996). 
It is also worth briefly commenting upon the faunal remains associated with the cat assemblage in E21. As mentioned above, other animal remains recovered in this pit included a whole horse skull, a goat horncore and a chicken egg. Whilst this association in a single pit may have been coincidental, we cannot discount the possibility that the skinning episode at El Bordellet site may have been accompanied by some type of symbolic ritual. Magical pagan rites outside the Christian canons are common during the Middle Ages (Mills, 1998; Bailey, 2001). The problem is that these types of rituals are often heterodox both in the elements and practices. However, the symbolic and magical significance given to elements such as eggs or animals such as goats is well known in medieval Spain (Morales, 1996; Herrero, 2010; García \& Ruiz, 2012). The coburial of hens and cats has also been noted elsewhere in Europe: the fill of a late fifteenth- to early sixteenth-century post-hole in a wall construction trench at the Bedern Foundry, York, contained the partial skeleton of a cat, together with several hens (Bond and O'Connor, 1999: 368). A similar (unpublished) instance was recoded at Broadgate East, Lincoln (Bond and O'Connor, 1999: 368). In such cases, a commemorative ritual undertaken in advance or during building construction seems likely. Cats also occupied a magical space in medieval Europe. They were associated with witches and heretics and it was believed that the devil could transform himself into a cat (Metzler, 2009). In the early $15^{\text {th }}$-century hunting text, The Master of the Game, Edward Duke of York wrote that, 'if any beast had the Devil's spirit in him, without doubt it is the cat' (cited in McNelis, 1997: 71). This symbolic association has persisted until modern times (Busquets, 1987; Gomis, 2014).

The use of cats in symbolic contexts within the same study area has been documented at the late antiquity site Els Mallols, situated in the province of Barcelona and dated between 5th and 7th centuries AD. Here, three pits contained domestic cat remains in anatomical position but with no evidence of skinning. One of the structures (E-183) was a collective human burial where five individuals were buried accompanied by one cat, 11 dogs and a few other animal remains. In a second structure (E-130) one cat, one sheep and a horse skull were recovered. Finally, a third structure (E-221) included one cat, four pigs, one sheep and three cattle skulls. These assemblages were interpreted as pagan rituals associated with a funerary context (Nadal \& Estrada 2007). The sample here studied from El Bordellet site is similar to those cases, especially to E-130. However, the archaeological evidence is insufficiently clear to confirm that the skinning of cats and the possible pagan rituals are related.

\section{Conclusions}

The domestic cat assemblage recovered from El Bordellet site comprised a total of nine young individuals. Zooarchaeological and taphonomic analysis indicates that all the animals were 
skinned. The type of deposit, the age of the cats, the breakage pattern and the presence and location of cut marks, all indicate that the cats were exploited for fur. Once skinned, the animal carcasses were thrown complete into the pit and all variables suggest that cats were not consumed.

The association of the cats with other scattered faunal remains in the pit (horse skull, goat horn and chicken egg) may be coincidental; however, it may suggest that the skinning was accompanied by a pagan ritual.

This study represents the first conclusive evidence of cat fur exploitation in the medieval Christian Iberia. This activity has been widely documented in numerous sites from northern Europe, especially Britain and Ireland. The scarcity of zooarchaeological studies of medieval cat assemblages, where the taphonomic analysis is considered, is the most plausible explanation for the lack of prior evidence in the Mediterranean.

\section{Acknowledgements}

Ll. Lloveras was funded by postdoctoral fellowships (BP-A2 00112011 and BPB 00140 2014) from the Secretaria d'Universitats i Recerca del Departament d'Economia i Coneixement de la Generalitat de Catalunya and COFUND programme (Marie Curie Actions). Financial support from research projects HAR2014-55131 from the Ministerio de Ciencia e Innovación (MICINN) and SGR2014-108 from the Generalitat de Catalunya are gratefully acknowledged. The excavation at El Bordellet site was conducted under permissions of Servei d'Arqueologia of Generalitat de Catalunya, special thanks to Magí Miret, commissioner of this service. Thanks also to the three anonymous reviewers whose critical comments helped us to improve our paper. 


\section{References}

Albarella U, Davis SJM. 1994. The Saxon and Medieval Animal Bones Excavated 1985-1989 from West-Cotton, Northamptonshire. English Heritage Ancient Monuments Laboratory Report 17/94: London.

Albarella U, Beech M, Mulville J. 1997. The Saxon, Medieval and Postmedieval Mammal and Bird Bones Excavated 1989-91 from Castle Mall, Norwich, Norfolk. English Heritage Ancient Monuments Laboratory Report 72/97: London.

Alòs C, Camats A, Monjo M, Solanes E, Alonso N, Martínez J. 2007. El Pla d'Almatà (Balaguer, La Noguera): primers aportacions interdisciplinàries a l'estudi de les sitges I els pous negres de la zona 5. Revista d'Arqueologia de Ponent 16-17: 145-168.

Amigó J, Barberà J, Cortadella J, Guasch D, Solias JM, Cortés MA. 1986, El Bullidor, Jaciment medieval. Estudi de materials i documentació. Quaderns d'Estudis Santjustencs. III: Sant Just Desvern.

Arthur P, Albarella U, Bruno B, King S. 1996. "Maseria Quattro Macine" - a deserted medieval village and its territory in Southern Apulia: an interim report of field survey, excavation and document analysis. Papers of the British School of Rome 64: 181-237.

Bailey M. 2001. From sorcery to witchcraft. Clerical conceptions of magic in the later Middle Ages. Speculum 76: 960-990.

Berman E. 1976. The time and pattern of eruption of the permanent teeth of the cat. Laboratory Animal Science 24 (6): 929-931.

Binford, LR. 1981. Bones: Ancient Men and Modern Myths. Academic Press: New York.

Bobis L. 2000. Le chat. Histoires et legendes. Ed. Fayard: Paris.

Bökönyi S. 1974. History of domestic mammals in Central and Eastern Europe. Akadémiai Kiadó: Budapest.

Bond, J. O’Connor, T. P. 1999. Bones from Medieval Deposits at 16-22 Coppergate. The Archaeology of York 15/5. London: Council for British Archaeology.

Bonde RLF. 2001. The Role of the Feline in the Medieval Society in the North Atlantic Region. Unpublished academic Document (B.Sc. Thesis). University of Bradford: Bradford.

Busquets E. 1987. Els animals segons el poble. Editorial Millà. Barcelona. 
Crezzini J, Boschin F, Boscato P, Wierer V. 2014. Wild cats and cut marks: Explotation of Felis silvestris in the Mesolithic of Galgenbühel/Dos de la Forca (South Tyrol, Italy). Quaternary International 330: 52-60.

Davis SJM. 1987. The Archaeology of Animals. Routledge: London.

De Grossi J. 1997. The introduction of the domesticated cat in Italy. Anthropozoologica 25-26: 789-792.

De Grossi J, De Venuto G. 2006. Indagini archeozoologiche presso il centro medievale di S. Salvo (Cheiti). In Atti $5^{\circ}$ Convegno Nazionale di Archeozoologia, Tagliacozzo A, Fiore I, Marconi S, Tecchiati U. (dirs.). Museo Civico di Rovereto: Rovereto; 293-297.

De Venuto G. 2006. Il gatto nel Medievo: recenti acquisizioni dal sitio archeologico di Canne della Battaglia (Barletta). Atti $5^{\circ}$ Convegno Nazionale di Archeozoologia, Tagliacozzo A, Fiore I, Marconi S, Tecchiati U. (dirs.). Museo Civico di Rovereto: Rovereto; 311-315.

Dodson P, Wexlar D. 1979. Taphonomic investigations of owl pellets. Paleobiology 5: 245265.

Driesch A von den. 1973. Nahrungsreste tierischer Herkunft au seiner tartessischen und einer spatbronzezeitlichen bis Iberischen Siedlung in Südspanien. Studien über frühe Tierknochenfunde von der Iberischen Halbinsel 4: 9-31.

Driesch A von den. 1976. A Guide to the Measurement of Animal Bones from Archaeological Sites. Peabody Museum Bulletin 1. Harvard University, Harvard.

Driscoll CA, Menotti-Raymond M, Roca AL, Hupe K, Johnson WE, Geffen E, Harley EH, Delibes M, Pontier D, Kitchener AC, Yamaguchi N, O’Brien SJ, Macdonald DW. 2007. The Near Eastern origin of cat domestication. Science 317: 519-523.

Fairnell EH. 2003. The Utilisation of Fur-Bearing Animals in the British Isles. A Zooarachaeological hunt for data. MSc Dissertation. Department of Archaeology. University of York: York.

Gallart J, Giralt J, Miró JM, Vives E. 1991. L'excavació de l'església de Sant Martí de Lleida. Monografies d'Arqueologia Urbana nº4: Lleida.

García MR, Ruiz F. 2012. Animales simbólicos en la Historia. Desde la Protohistoria hasta el final de la Edad Media. Síntesis ed.: Madrid.

Gautier A. 1990. La Domestication. Et l'homme créa ses animaux. Errance: Paris. 
Gomis C. 2014. Zoologia popular catalana. Editorial Sidillà: Besalú.

Grau I. 2014. Waste management at early medieval rural sites in northern Spain: taphonomic issues for interpreting faunal remains. Quaternary International 330: 97-108.

Grayson DK. 1984. Quantitative Zooarchaeology. Topics in the Analysis of Archaeological Faunas. Academic Press: Orlando.

Greenfield HJ. 1999. The origins of metallurgy: distinguishing stone from metal cut-marks on bones from archaeological sites. Journal of Archaeological Science 26: 797-808.

Hatting T. 1990. Cats from Viking age Odense. Journal of Danish Archaeology 9: 179-193.

Haynes G. 1980. Evidence of carnivore gnawing on Pleistocene and Recent mammalian bones. Paleobiology 6: 341-351.

Herrero J. 2010. Bestiario románico en España. Cálamo ed.: Palencia.

Lewis JE. 2008. Identifying sword marks on bone: criteria for distinguishing between cut marks by different clases of bladed weapons. Journal of Archaeological Science 35: 20012008.

Lignereux Y, Périn N, Peters J. 2000. Les vestiges fauniques de vertébres du site ibérique et romain de la Picola (Santa Pola, Alicante). In Le site antique de La Picola à Santa Pola (Alicante, Espagne), Badie A, Gailledrat E, Moret P, Roudillard P, Sánchez MJ, Sillières P. (eds.). Éditions Recherche sur les civilisations. Casa de veázquez, Paris-Madrid.

Lloveras Ll, Moreno-García M, Nadal J. 2009. Butchery, Cooking and Human Consumption Marks on Rabbit (Oryctolagus cuniculus) bones: An experimental Study. Journal of Taphonomy 7: 179-201.

Luff R, Moreno-García M. 1995. Killing cats in the Medieval Period. An unusual episode in the history of Cambridge, England. Archaeofauna 4: 93-114.

Lyman RL. 1994. Vertebrate Taphonomy. Cambridge University Press: Cambridge.

Mallye JB. 2011. Réflexion sur le dépouillement des petits carnívores en contexte archéologique: Apport de l'expérimentation. Archaeofauna 20: 7-25.

Maltby JM. 1979. The Animal Bones from Exeter 1971-1975. Exeter Archaeological Reports 2. University of Sheffield: Sheffield. 
Martínez RM, Carmona R. 2013. Animales en contextos arqueológicos medievales de Priego de Córdoba. Una aproximación a partir de los depósitos estratificados en silos y pozos. Antiqvitas 25: 209-234.

McCormick F. 1988. The domesticated cat in early Christian and Medieval Ireland. In Keimelia: Studies in Medieval Archaeology and History in Memory of Tom Delaney, Mac Niocaill G and Wallace P F (ed.). Galway University Press: Galway; 218-228.

McNelis JI. 1997. 'A greyhound should have 'Eres in pe manere of a serpent': Bestiary material in the hunting manuals Livre de chasse and The Master of the Game'. In Animals and the Symbolic in Medieval Art and Literature, L.A.J.R. Houwen (ed.),. Groningen, Egbert Forsten, $67-75$

Mestre Robert.1996. El Llibre del Coch. Curial edicions: Barcelona (original of 1520).

Metzler I. 2009. Heretical cats: animal symbolism in religious discourse. Medium Aevum Quotidianum 59: 16-32.

Mills L. 1998. The Pagan Middle Ages. Boydell Press: Suffolk.

Moloney C, Coleman R. 1997. The developement of a medieval street frontage: the evidence from excavations al 80-86 High Street, Perth. Proceedings of the Society of Antiquaries of Scotland 127: 707-782.

Morales MCD. 1991. Zoohistoria: Reflexiones acerca de una nueva disciplina auxiliar de la ciencia histórica. Espacio, Tiempo y Forma. Serie III: Historia Medieval 4: 367-383.

Morales MCD. 1996. El simbolismo animal en la cultura medieval. Espacio, Tiempo y Forma. Serie III: Historia Medieval 6: 229-255.

Nadal J, Estrada A. 2007. Estudi de la fauna. In Els Mallols. Un jaciment de la plana del Vallès entre el neolític i l'antiguitat tardana (Cerdanyola del Vallès, Vallès Occidental), Francès J. (ed.). Generalitat de Catalunya. Departament de Cultura i Mitjans de Comunicació: Barcelona; 265-306.

Noodle BA. 1977. Mammal bone. In Excavations at King's Lynn, 1963-1970, Clarke H and Carter A (eds.) The Society for Medieval Archaeology. Monograph Series 7: Durham; 378-399.

Palou H, Rieth E, Izaguirre M, Jover A, Nieto X, Pujol M, Raurich X, Apestegui C. 1998. Excavacions arqueològiques subaquàtiques a cala Culip 2: Culip VI. Monografies del CASC. Generalitat de Catalunya: Girona. 
Segura S, Medina E. 2010. Memòria d'excavació Eix Diagonal (Carretera C-15), projecte de construcció I explotació. Condicionaments C-15 I C-37. Vilanova I la Geltrú-Manresa (Tram 1) exteriors I i II (Vilafranca del Penedès, Alt Penedès). Unpublished field archaeological Report. Servei d'Arqueologia I Paleontologia. Generalitat de Catalunya: Barcelona.

Serjeantson D. 1989. Animal remains and the tanning trade. In Diet and Crafts in Towns. The Evidence of Animal Remains from the Roman to the Post-Medieval Periods, Serjeantson D and Waldron T (eds.) British Archaeological Reports British Series 199: Oxford; 129-146.

Smith RN. 1969. Fusion of ossification centres in the cat. Journal of Small Animal Practice 10: 523-530.

Valenzuela S, Valenzuela L, Saula O, Colet A, Mercadal O, Subiranas C, Nadal J. 2014. Sechita and Kashrut: identifying Jewish populations through zooarchaeology and taphonomy. Two examples from medieval Catalonia (North-Eastern Spain). Quaternary International 330: $107-117$.

Vigne JD, Guilaine J. 2004. Les premiers animaux de compagnie, 8500 ans avant notre ère?..ou comment j'ai mangé mon chat, mon chien et mon renard. Anthropozoologica 39(1): 249-273.

Vigne, JD, Guilaine, J, Debue K, Haye L, Gérard P. 2004. Early taming of the cat in Cyprus. Science 304: 259.

Yvinec JH. 1993. La part du gibier dans l'alimentation du haut Moyen Âge. In Explotation des animaux sauvages a travers le temps, Desse J and Audoin -Rouzeau F (eds.). Éditions APDCA: Juan-les-Pins; 491-504. 


\section{List of tables}

Table 1: Skeletal profile (in terms of NISP, NME and RA\%) and completeness (C\%) in the cat assemblage from El Bordellet.

Table 2: Description of the butchery, fracture patterning, age and completeness of each cat recovered from El Bordellet.

Table 3: Crania (A) and mandible (B) measurements of cats from El Bordellet in mm. n: number; $r$ : range; $x$ : mean; s: standard deviation; v: coefficient of variation. Numbers of measurements refer to those described by von den Driesch (1976).

Table 4: Comparison of mandibular length measurements of European medieval cats in mm. $\mathrm{n}$ : number; r: range; $x$ : mean; s: standard deviation; v: coefficient of variation; t: Student's t value; p: probability.

Table S1: List of cat remains recovered from archaeological medieval sites (9th-15th centuries $\mathrm{AD})$ in North-eastern Iberia (Catalonia).

\section{List of figures}

Figure 1: Map of the Iberian Peninsula to show the location of El Bordellet and distribution of the archaeological structures at the site: E-21 is labelled in green.

Figure 2: Faunal remains recovered from E-21. A: equid skull; B: domestic cat assemblage; C: goat horncore; D: eggshell.

Figure 3: Left: histogram of total length of mandible in mm (1, after von den Driesch 1976). Right: scatterplot of the vertical ramus height against total length of the mandible in $\mathrm{mm}(8$ and 1, after von den Driesch 1976).

Figure 4: A: example of one of the recovered cats; B,C: parts of skull and mandible still in anatomical connexion before the study; D: skull with a pre-mortem or peri-mortem canine partial ablation.

Figure 5: Examples of cut and chop marks and green fractures on metatarsals.

Figure 6: Examples of light cut marks in cranium elements. A, B: cut marks on mandibles (A1 and $\mathrm{B} 1$ are details).

Figure S1: Schematic stratigraphic rendering of North-South and East-West views of pit E-21.

Figure S2: relative abundance (RA\%) of different parts of cat skeleton at El Bordellet. Abbreviations: cra: cranium, in: incisors, ca: canines, pre: premolars, mol: molars, man: mandible, sca: scapula, hum: humerus, ra: radius, ul: ulna, inn: innominate, fem: femur, pat: patellae, tib: tibia, fi: fibula, cal: calcaneum, ast: astragalus, carp: carpal bones, tar: tarsal bones, 
mtc: metacarpus, mtt: metatarsus, phal1/2: $1^{\text {st }}$ and $2^{\text {nd }}$ phalanges, phal3: $3^{\text {rd }}$ phalanges, vc: cranial vertebrae, vt: thoracic vertebrae, vl: lumbar vertebrae, sac: sacrum, vcu: caudal vertebrae, rib: ribs, ster: sternum.

Figure S3: scatterplot of the vertical ramus height against total length of the mandible in $\mathrm{mm}(8$ and 1, after von den Driesch 1976). Abbreviations used for the sites: EB- El Bordallet; BCBene’t Court; CdB- Canne della Battaglia; CM- Castle Mall; C- Colchester; HA- Haithabu; HO- Höxter 